\title{
Mobile Advertising Technology Acceptance Model (M-TAM): An Extension of TAM in Mobile Marketing Context
}

\author{
Mirza A. Haq * Arsalan Mujahid Ghouri ${ }^{\dagger}$
}

\begin{abstract}
Mobile advertising technology has revolutionized the way companies interact with their customers. This has offered both marketers and consumers the advantages of convenience, flexibility, and ubiquity etc. Irrespective of the advantages of mobile advertising technology, it is not easy for marketers and researchers to form adoptable mobile advertising technology for consumers without being in a position to precisely foresee consumers' behavioural outcome. Additionally, this field appears to be scant in academic researches. The current study was initiated to empirically examine the influence of m-advertising technological factors (i.e., ease of use, usefulness, personalization and credibility) on consumers' adoption behaviour. These factors were also mediated by emotional value in order to influence end users' adoption behaviour. A quantitative approach based upon a cross-sectional administered survey was employed to collect the data from university going student as respondents. The Partial Least Square (PLS) two step path modelling was used through SmartPLS 3 to test the direct and indirect hypotheses. The results indicate that mobile advertising technology factors (i.e., ease of use, usefulness, personalization and credibility) directly and indirectly impact consumers' adoption behaviour through emotional value. Based on the findings of the study, theoretical and practical contributions along with certain limitations and future researches recommendation are discussed consequentially.
\end{abstract}

Keywords: Emotional value, attitude, adoption intention, TAM model.

\section{Introduction}

Mobile advertising technology had transformed the principles on which marketers and practitioners communicate to their consumers (Grant \& O'Donohoe, 2007; Nah, Siau, \& Sheng, 2005; Nel \& Boshoff, 2017). Recently, the rapid pace of smart phones and other similar technological gadgets adoption has undoubtedly created a land of opportunities for marketers and advertisers to build long term relations with their customers through this highly customized and interactive platform (Pagani \& Malacarne, 2017; Sultan \& Rohm, 2005). Advertisers and end users both may gain the advantages of personalization, connectivity and convenience through mobile phone advertisements (Friedrich, Gröne, Hölbling, \& Peterson, 2009). However, regardless of these benefits offered through mobile advertisement, it is difficult for practitioners and advertisers to capitalize maximum advantages

\footnotetext{
*Department of Business Administration, IQRA University, Pakistan. E-mail: amin.ulhaq@iqra.edu.pk

$\dagger$ Department of Business Administration, Universiti Pendidikan Sultan Idris, Malaysia.

E-mail: dr.arsalan@iqra.edu.pk
} 
without being in a situation to irrefutably anticipate consumer's behavioral consequences (Van Ittersum \& Feinberg, 2010).

A number of reasons can be attributed to the widespread use of mobile phones. Grant and O'Donohoe (2007) believe that the lively combination of audio and visual components incorporated into a single experience, and the ease with which media content can be shared, has made the use of mobile phones more rampant. Further, the integration of internet and computing features into a mobile device (Nah et al., 2005) has led to an easy and convenient way of sharing information anywhere and anytime (Tanakinjal, Deans, \& Gray, 2010).

Marketing via cell phones have become an essential medium to facilitate customers and firm interaction, transfer relevant information, and maintain long run relations (Grant \& O'Donohoe, 2007). Communication of marketing material and dissemination of information was never this easy until the advent of mobile marketing (Nysveen, Pedersen, Thorbjørnsen, \& Berthon, 2005). It provides information about the offerings and prices to facilitate their comparison and enable better adoption decision. On the darker side, it has also led to a bigger difficulty for marketers to predict adoption behavior because of this overabundance of information at customers disposal. As a result, customers are now have more expectations for transparent information and opportunity for instantaneous interactions with the relevant firm.

Irrespective of the fact that mobile advertising technology offers lots of advantages, the adoption rate of this new technology is still comparatively low (Chen \& Hsieh, 2012). As per the statistics, irrelevant and fake promotional activities noted on mobile phones (Turow, King, Hoofnagle, Bleakley, \& Hennessy, 2009) may discourage consumers to adopt this particular technology (Zarmpou, Saprikis, Markos, \& Vlachopoulou, 2012). One of its reasons and explanations was offered from academic perspective in form of Technology acceptance model [TAM] (Davis, Bagozzi, \& Warshaw, 1989). TAM has appeared in literature as one of the most regarded model for explaining user's acceptance and adoption of information technology due to its robustness across technological domains - such as word processor (Davis et al., 1989), email system (Szajna, 1996), graphics systems (Venkatesh \& Davis, 1996), virtual workplace system (Venkatesh, 1999), data retrieval system (Venkatesh \& Morris, 2000) and proprietary information system (Venkatesh \& Davis, 2000).

Despite of the fact that many studies have utilised TAM to explain user intention to use information technology, this model is still very general and do not provide comprehensive explanation w.r.t. each particular domain (Kalaiarasi \& Srividya, 2012). Each domain has its own unique characteristics which may further be incorporated in existing TAM model to better explain user's adoption behavior in that particular domain. Similarly, mobile advertising technology also has some unique contextual characteristics which shall be considered in TAM to enhance current understanding on m-advertising adoption behavior. Y. J. Kim and Han (2014) advocated that cognitive factors (such as personalization and credibility) can be incorporated in TAM in the context of mobile advertising to better predict m-advertising adoption behavior.

In addition to the above, it is also essential to incorporate emotional aspects in existing cognitive models of information technology adoption (H.-W. Kim, Chan, \& Gupta, 2007; Y. J. Kim \& Han, 2014) to see a larger picture of this phenomenon. Emotions play an important role in our lives as they guide our beliefs and attitudes, which influence our 
intentions, and behavior (Gratch \& Marsella, 2004; Gendron \& Barrett, 2018). Emotions portray a mental state of promptness that results from cognitive evaluations of objects or thoughts and subsequently influence specific action or response (Bagozzi, Gopinath, \& Nyer, 1999). Researches (H.-W. Kim et al., 2007; Ladhari, Souiden, \& Dufour, 2017) highlighted the need to incorporate emotional factors to examine technology adoption behavior. To fill this gap, current research is aimed to examine the role of ease of use, personalization, usefulness and credibility to collectively predict the intentions to adopt mobile advertising technology including the degree to which these relationships are mediated by emotional value.

\section{Conceptual Framework}

The foundations of current research has its underpinnings from the model proposed for technology acceptance (i.e., TAM). The fundamentals of TAM defined in Fishbein's reasoned action theory (Fishbein \& Ajzen, 1977) and Ajzen's planned behavior theory (Ajzen, 1991). Davis et al. (1989) was the first one who proposed TAM with a specific objective to comprehend user's technology adoption behavior. Further, Technology Accepted Model (TAM) explains the adoption behavior of an individual by means of two main perceptual factors. One is perceived usefulness which describes an individual's belief that the extent to which utilizing a particular technology may enhance one's capability to perform better. Second is ease of use which explains an individual's belief that the extent to which easiness is derived through utilizing that technology.

\section{Figure 1}

Theoretical Framework

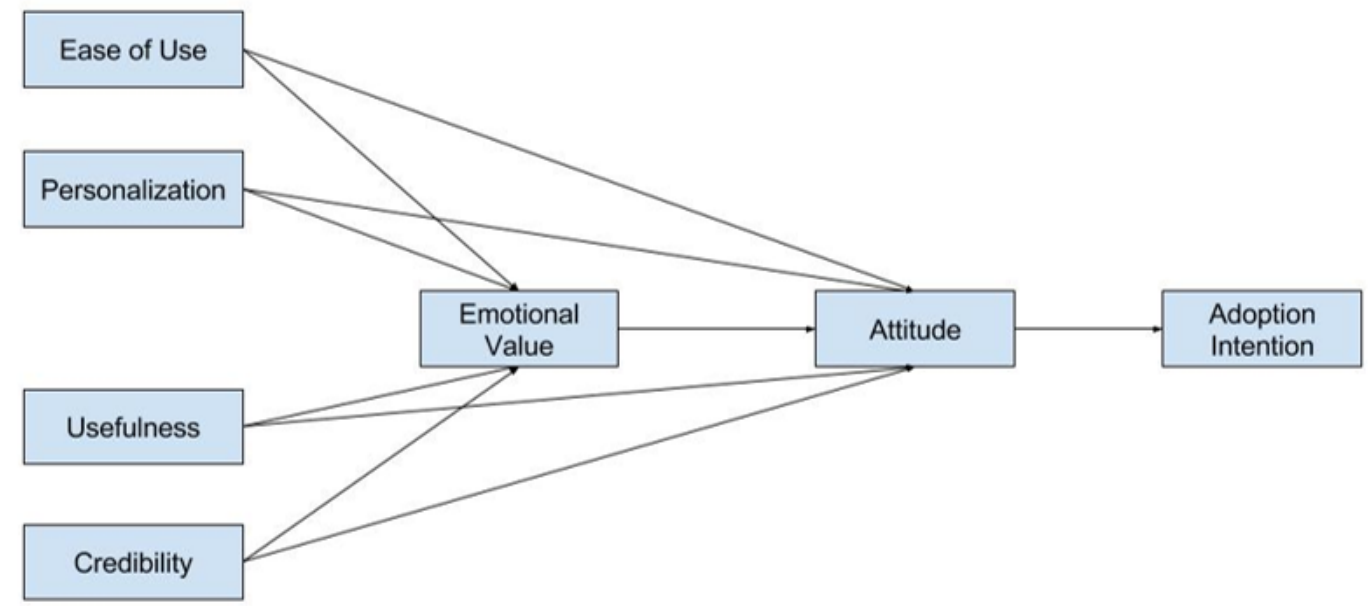

Mobile advertising offer both the cognitive and affective benefits and marketers can design visually rich interfaces that customer enjoy. Moon and Kim (2001) advocated that cognitive benefits have a positive impact on customer purchase behavior. Past researches 
have used two elements of TAM (PEOU and PU) to discover the adoption behavior in context of m-advertising (Cyr, Head, \& Ivanov, 2006; Bruner II \& Kumar, 2005; Wakefield \& Whitten, 2006). Besides PU and PEOU, this study also includes personalization and credibility as important cognitive elements of m-advertising technology adoption as suggested by Balan and Zegreanu (2012).

In addition to above discussions, Sheng and Teo (2012) revealed that affective benefits have a positive impact on customer purchase behavior. They suggested that when individuals are in the pleasant experiential state due to credible, personalized and useful information obtained through mobile advertisements, they sense affective benefits - such as being happy and feeling good - in addition to cognitive benefits. Furthermore, theory of consumption value advocates that consumers attribute distinctive values to product and that these, in succession, will incite adoption and usage behavior through emotional values (Sheth, Newman, \& Gross, 1991; Soutar \& Sweeney, 2003). Thus, under the lines of Soutar and Sweeney (2003); Sheng and Teo (2012), this research has also investigated emotional value as a mediator between antecedents and outcomes of mobile advertising technology adoption.

\section{Review of Literature}

\section{PEOU and PU}

The original TAM postulates that consumers' behavioral intention (BI) for adopting any technology can be comprehended through the factors such as perceived ease of use (PEOU) along with the perceived usefulness (Schierz, Schilke, \& Wirtz, 2010). The PEOU constructs, which is regarded as the intrinsic indicator of TAM, considers the flexibility, ease of use in learning and clarity for technological interface (Davis et al., 1989; Mathieson, 1991; S. Gao \& Zang, 2016; Aydin \& Karamehmet, 2017). The rational of TAM for considering these variables is the likelihood of a person's behaviour that, in a certain manner, prompts a result which considers an observable conviction (Davis et al., 1989). Past researches have used two elements of TAM (PEOU and PU) to discover the adoption behaviour in context of m-advertising (Bruner II \& Kumar, 2005; Cyr et al., 2006; Wakefield \& Whitten, 2006; Maduku, Mpinganjira, \& Duh, 2016; Aydin \& Karamehmet, 2017). Hence it is proposed that:

$H_{1}$ : There is a significant and direct impact of PEOU on attitude towards m-advertising technology adoption.

$\mathrm{H}_{2}$ : There is a significant and direct impact of $P U$ on attitude towards m-advertising technology adoption.

\section{Credibility}

Credibility in the context of advertisement is defined as acceptability, honesty and perception in the eye of viewer regarding the advertisement (MacKenzie \& Lutz, 1989; Lim, Ri, 
Egan, \& Biocca, 2015). Another study elaborates credibility as thought and expectation of a customer about the authenticity and truthfulness of information of message being delivered in advertisement (Daugherty, Logan, Chu, \& Huang, 2008). Credibility also refers to the acceptance of customers on the basis of expectations developed in their mind regarding any product or brand (S. Gao \& Zang, 2016). Past experience of using a product also play significant role in credibility of advertisement. In terms of mobile advertisement, if a company fails to deliver valued information that is factual in nature, the customer or viewer tends to reject it that can harm company's reputation. Past researches signify that credibility of a particular brand or product play an important role in influencing purchase behaviour of consumers (S. Gao \& Zang, 2016; Aydin \& Karamehmet, 2017). Therefore, it is hypothesized that:

$H_{3}$ : There is a significant and positive impact of credibility on attitude towards $m$ advertising technology adoption.

\section{Personalization}

In mobile advertising, personalization is another significant feature which grabs the attention of the customers (Maduku et al., 2016). As per Leppäniemi and Karjaluoto (2008), personalization signifies that the degree to which the advertised message is according to the needs, expectations and preferences of the customers. Personalization plays a vital role in forming positive perception of consumers towards mobile advertisement (M.-K. Kim, Joo, \& Park, 2017). Consequently, customers anticipate exceptionally modified offerings on their mobile phones (Bauer, Reichardt, Barnes, \& Neumann, 2005).

Feedback and history are useful tools to acquire data regarding their preferred decisions and this might be used by advertisers and marketers to align their offerings in the same manner. This may give a chance to advertisers to provide their clients in an individual manner that can assemble persisting associations with them. Furthermore, earlier studies (Carroll \& Barnes, 2005) additionally it also explained that more response and positive reactions can be noticed by customers if the advertisement massages reflects their demand and needs. In this manner, it is recommended that:

$H_{4}$ : There is a significant and direct impact of personalization on attitude towards M-advertisement technology adoption.

\section{Emotional Value}

The emotional value with respect to mobile technology has gained popularity especially because of feel and excitement acquired while utilizing this technology. Moreover, madvertising technology frequently facilitate emotional communication, for example, by means of logos, picture messages, chat services and ring tones that can likewise be sent as gifts (Pura \& Gummerus, 2007; Yeong, Kheng, Leong, \& Tan, 2017). Subsequently, in mobile entertainment services emotional value is an important factor to influence mobile services acceptance. Ovčjak, Heričko, and Polančič (2016) carried out a systematic litera- 
ture on role of emotions in mobile services acceptance and identified nine types of emotions present in literature mobile services acceptance literature. It is further determined that out of the nine emotions, enjoyment is spotted as the most important value to achieve mobile services acceptance.

Grounded on Lutz, MacKenzie, and Belch (1983) 'affect transfer model', IS user can judge the effectiveness when one senses usefulness, which positively influences one's attitudes. As emotional value triggers consumers to acknowledge the effectiveness of products, the derived emotional experience is positively interconnected with functional efficacy (Hsu \& Lin, 2015). Moreover, according to Wang, Po Lo, Chi, and Yang (2004) emotional value has a positive influence on behavioural intention. The connection between usage intention and usage is consistent with the technology acceptance model (Ajzen, 1991; Davis et al., 1989). However, as per Delone and McLean (2003); Hsu and Lin (2015), IS success proposes that a very positive experience in operating a system will be shifted into a positive perception of usefulness through emotional value. Moreover, this insight affects users to evaluate the functional value of a system through emotional value; thereby directing to better gratification connected with usage. As a result, users are prone to utilize the system through better functional value and satisfaction linked with usage through emotional value (Oliver, 1996; Atrakul \& Hu, 2017). Consequently, it is hypothesized that:

$H_{5}$ : Emotional value mediates the effect of ease of use [H5a], usefulness [H5b], personalization [H5c] and credibility [H5d] on attitude to adopt mobile advertising technology.

\section{Research Methodology}

The objective of this research was to investigate the role of usefulness, ease of use, credibility and personalization in order to collectively predict the intentions to adopt mobile advertising technology including the degree to which these relationships are mediated by emotional value. A quantitative approach was adopted to achieve this objective, by means of which, data was gathered in numbers for the factors and statistical methods were performed to evaluate findings as per the recommendation of Creswell and Creswell (2017).

The samples targeted in the study were students in private universities and utilizing the telecommunication service of any one of the service providers in Pakistan - such as Telenor, Ufone, Zong, Mobilink and Warid. In Pakistan, many university-aged consumers view themselves as trendsetters and they have specific needs and wants as consumers. For these reasons, university-aged consumers are one of the most coveted consumer segments for businesses and marketers (Carter, 2008). According to Howell (2012), university-going students in private sector have tremendous purchasing power, well-educated and they are most likely to have high earning potential in the future. Therefore, university students belonging to private sector were counted as the target population in this research.

The researchers contacted Higher Education Commission to get the updated list of enrolled students of each private university as HEC was the only government regulatory authority dealing with all the matters of universities in Pakistan. However, they failed to get the updated and complete list from HEC or the registrar office of the universities. 
Therefore, the researcher had to depend on the total population of 21 private universities.

As mentioned in HEC report on university wise year of enrolment (2014-15), a count of 64064 students who were attending university and registered among private sector universities located in city of Karachi (Sindh) Pakistan. The reason behind Karachi as the focus of study is because it is the representative of whole Pakistan. People from all statures of society and belonging to varying degrees of income groups and also following different cultures and religions reside in the city of Karachi. Hence, it can justifiably represent the Pakistani society as a whole.

Multi-stage area sampling method, as deployed by Allen et al. (2002), was used for the study in order to gather the sample required for analysis. This implied that the researchers, at first stage, selected Pakistan as country. Then, the researchers segregated the regions according to the four provinces of Pakistan; which were Punjab, Sindh, NWFP and Baluchistan. In third step, Sindh was selected as a province due to presence of highest number of private sector universities. In last step, Karachi was selected as city as $97 \%$ private sectors universities of Sindh were located in Karachi. The table mentioned below explains allocation and producers of target sample size.

Table 1

Details of Multi-stage Cluster Sampling

\begin{tabular}{|c|c|c|}
\hline Indicator & Sub Total & Total \\
\hline \multicolumn{2}{|c|}{ Total no. of Universities in Pakistan (Public + Private) } & 179 \\
\hline Federal & 33 & \\
\hline Punjab & 51 & \\
\hline Sindh & 50 & \\
\hline KPK & 30 & \\
\hline Baluchistan & 8 & \\
\hline Azad Jammu \& Kashmir & 7 & \\
\hline \multicolumn{2}{|c|}{ Total no. of Private Universities in Pakistan } & 75 \\
\hline Federal & 8 & \\
\hline Punjab & 24 & \\
\hline Sindh & 30 & \\
\hline KPK & 10 & \\
\hline Baluchistan & 1 & \\
\hline Azad Jammu \& Kashmir & 2 & \\
\hline \multicolumn{2}{|c|}{ No. of Private Universities in Sindh } & 30 \\
\hline Karachi & 29 & \\
\hline Hyderabad & 1 & \\
\hline No. of Private Universities & & 29 \\
\hline
\end{tabular}

For the purpose of gathering reliable and accurate data, four enumerators were contracted and prepared in regards to administration of the questionnaires and field work to gather data from the key informants. These enumerators were trained and facilitated with the detailed review of the questionnaires so that the respondents does not have any misunderstanding or ambiguity with respect to questionnaire items.

The research tool used in survey was the questionnaire which was divided into four sections. Section A asked the demographic details of the respondents. Section B contained the study questions on exogenous attributes of m-advertising technology - such as personalization, PEoU, PU and credibility - adapted from Feng, Fu, and Qin (2016); Muk and Chung 
(2015); Liu, Gao, and Long (2010) respectively. Section C portrayed the endogenous of advertisement through mobile appliances (adapted from Lee and Jun (2007); Soutar and Sweeney (2003); Xu (2006)). Section D enquired the open ended questions related to the mobile advertising technology.

\section{Results}

For the analysis of data gathered through surveys, a set of statistical procedures - for example, SEM, measurement model and mediation analysis - were performed through two step approach from SmartPLS 3. SmartPLS is the appropriate choice because it makes fewer assumptions about data distribution and is more robust to smaller sample size limitations. In addition, the objective of current research is to extend the previous seminal works by introducing emotional value as a mediator to influence consumers' attitude; therefore, application of PLS-SEM is suitable.

Table 2

Details of Private Universities in Karachi

\begin{tabular}{|c|c|c|c|}
\hline $\begin{array}{l}\text { Private Universities in Karachi } \\
\text { in Karachi }\end{array}$ & $\begin{array}{c}\text { Total Enrollment } \\
2014-2015\end{array}$ & $\begin{array}{c}\text { Proportion in } \\
\% \text { age }\end{array}$ & $\begin{array}{c}\text { Administered } \\
\text { Questionnaires }\end{array}$ \\
\hline Aga Khan University & 1693 & $2.64 \%$ & 11 \\
\hline Greenwich University, Karachi & 1134 & $1.77 \%$ & 7 \\
\hline Habib University Karachi & 108 & $0.17 \%$ & 1 \\
\hline Indus University Karachi & 2839 & $4.43 \%$ & 18 \\
\hline Institute of Business Management, Karachi & 3965 & $6.19 \%$ & 25 \\
\hline Institute of Business \& Technology, Karachi & 2161 & $3.37 \%$ & 13 \\
\hline Institute of Business Administration, Karachi & 3492 & $5.45 \%$ & 22 \\
\hline Iqra University, Karachi & 5801 & $9.06 \%$ & 36 \\
\hline Karachi Institute of Economics \& Technology & 3887 & $6.07 \%$ & 24 \\
\hline Karachi School of Business \& Leadership & 106 & $0.17 \%$ & 2 \\
\hline Preston University, Karachi & 4277 & $6.68 \%$ & 27 \\
\hline Jinnah University for Women5382 & 5382 & $8.40 \%$ & 34 \\
\hline Dadabhoy Institute of Higher Education & 5524 & $8.62 \%$ & 34 \\
\hline DHA Suffa University & 1035 & $1.62 \%$ & 6 \\
\hline Baqai Medical University & 1722 & $2.69 \%$ & 11 \\
\hline Hamdard University & 6921 & $10.80 \%$ & 43 \\
\hline Nazeer Hussain University & 118 & $0.18 \%$ & 1 \\
\hline Shaheed Zulfiqar Ali Bhutto Institute of Science and Technology & 5984 & $9.34 \%$ & 37 \\
\hline Sir Syed University of Engineering and Technology & 6030 & $9.41 \%$ & 38 \\
\hline Textile Institute of Pakistan & 275 & $0.43 \%$ & 2 \\
\hline Ziauddin University & 1610 & $2.51 \%$ & 10 \\
\hline Total & 64064 & $100.00 \%$ & 401 \\
\hline
\end{tabular}

Source: HEC website (http://hec.gov.pk/)

The measurement carried out with the reflective indicators were analyzed through the reliability and validity of the respective constructs. Reliability of constructs was evaluated through outer loadings, Cronbach's alpha and composite reliability of the indicators. See the Table 3 for details.

As indicated in the above table, the greater part of the indicators have their loadings more than of 0.70. As per the recommendations of Yoo and Alavi (2001), the factor loadings of each item has to be greater than 0.7 in a normal case. However, some researchers argued that factor loadings between 0.5 and 0.7 can be acceptable in case if their absence 


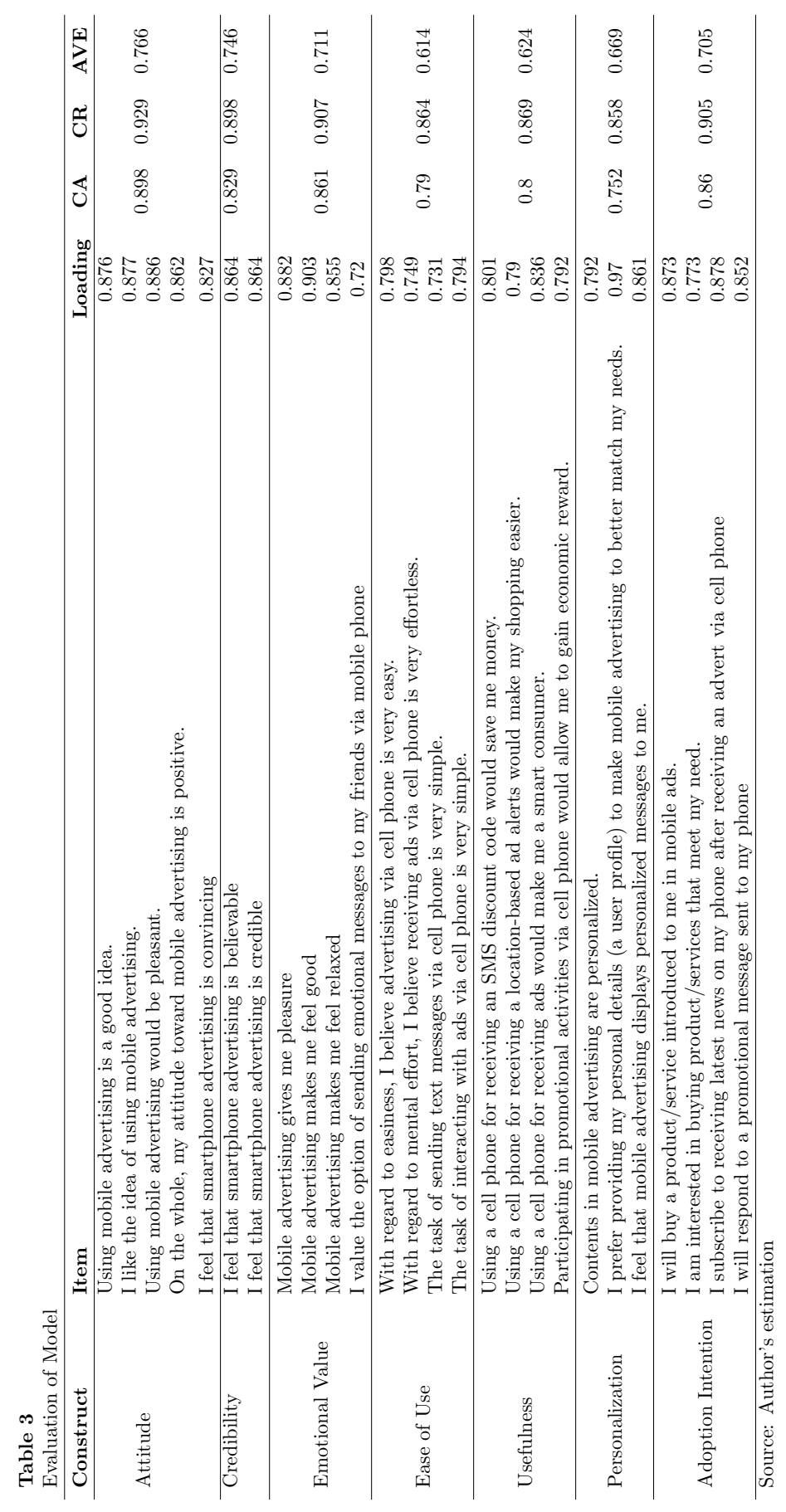


cause significant changes in Average Variance Extracted value (Wong, 2013). Likewise, the weaker external loadings of the items ( 0.4 or less) can be removed from the model (Hair, Hult, Ringle, \& Sarstedt, 2016). The loadings presented in Table 3 affirm the validity and reliability of the constructs as the loading of all the mentioned items is above 0.5 and 0.7 .

After external loadings, convergent validity was evaluated through the Cronbach's alpha, composite reliability and AVE. It is also worthy to mention that composite reliability is more stringent and preferred approach over Cronbach's alpha to assess convergent validity. The results revealed that all the variables in the table had shown their alpha value more than the threshold of 0.7 (Nunnally \& Bernstein, 1978; Peterson \& Kim, 2013). Moreover, the composite reliability of these variables were above 0.8 and AVE value was more than 0.5 ; which ensured the convergent validity in the proposed factors (Hair et al., 2016; Henseler, Ringle, \& Sinkovics, 2009).

\section{Figure 2}

M-advertising factors and behavioural outcomes

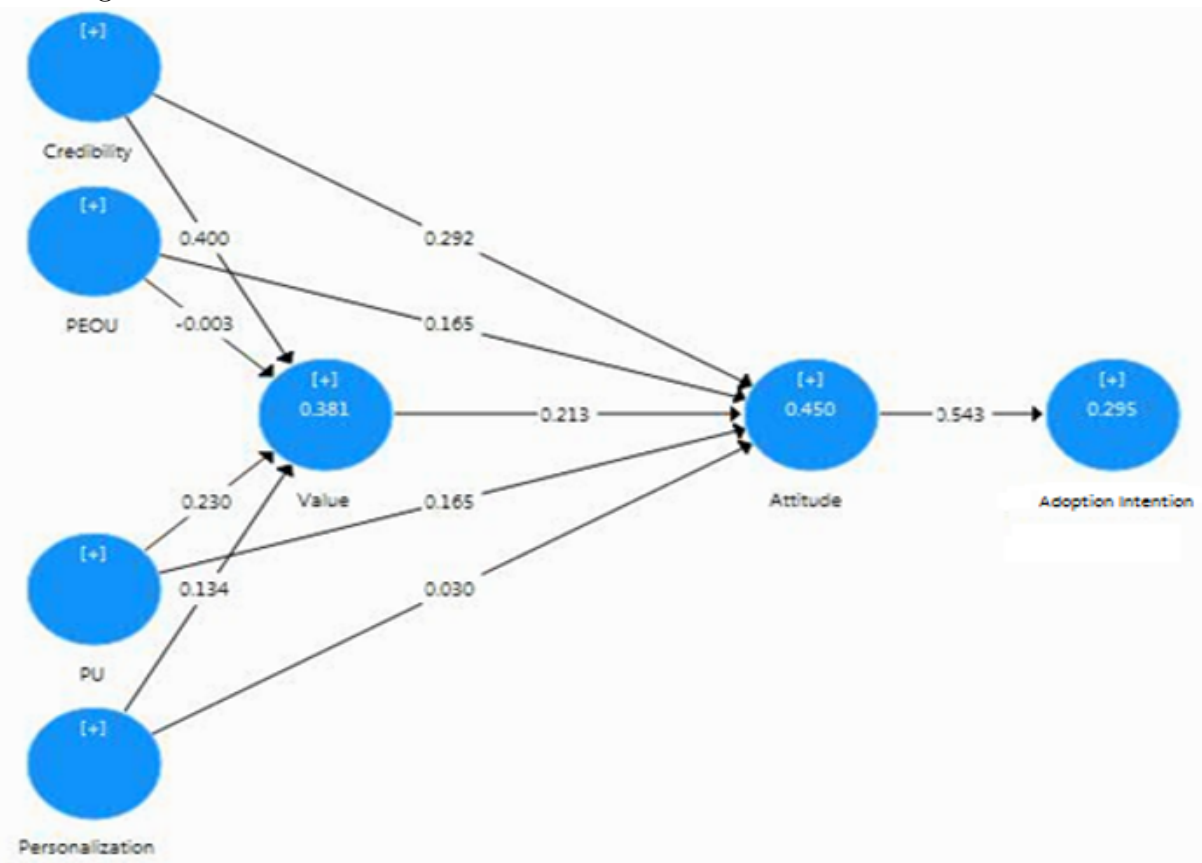


Table 4

\begin{tabular}{|c|c|c|c|c|c|c|c|c|}
\hline & & 1 & 2 & 4 & 5 & 6 & 7 & 8 \\
\hline 1 & Attitude & 0.878 & & & & & & \\
\hline 2 & Credibility & 0.579 & 0.861 & & & & & \\
\hline 4 & Ease of Use & 0.456 & 0.432 & 0.746 & & & & \\
\hline 5 & Usefulness & 0.522 & 0.527 & 0.538 & 0.798 & & & \\
\hline 6 & Personalization & 0.288 & 0.306 & 0.233 & 0.357 & 0.795 & & \\
\hline 7 & Emotional Value & 0.521 & 0.561 & 0.325 & 0.487 & 0.338 & 0.834 & \\
\hline 8 & Adoption Intention & 0.543 & 0.466 & 0.300 & 0.524 & 0.359 & 0.560 & 0.838 \\
\hline
\end{tabular}

For the discriminant validity in the research, this study has adopted the technique suggested by Fornell and Larcker (1981), in which it is recommended that square root of AVE estimation of all the latent variables has to be greater than the correlation among constructs of the study (Hair et al., 2016). Moreover, to assess the threat of collinearity, variance inflation factors (VIF) was calculated for all the exogenous constructs, and spotted under the threshold of 10 (Hair et al., 2016). The following criteria has been verified as shown in table 4.

The above figure shows the path analysis results between m-advertising components and mobile advertising technology adoption. In terms of m-advertising related components, perceived usefulness, perceived ease of use, personalization and credibility of mobile advertising technology were considered to have direct and indirect impact upon customer adoption behavior. For testing of hypothesis and model, PLS SEM was applied through SmartPLS 3 software.

The first hypothesis of the study deals with the direct influence of PEOU on attitude towards m-technology adoption behavior. According to the results, the direct relationship between PEOU and attitude towards adoption of m-advertisement technology adoption was significant (e.g., $\mathrm{p}<0.05$ ). In addition, the direction of relationship is positive; which infers that if m-advertising technology is perceived as easy to use, consumer will be more likely to form a positive attitude towards adopting it. Therefore, H1 is accepted.

Within this study's context, the second hypothesis mainly deals with the PU's direct relationship with m-advertising adoption behavior. As per the results, the relationship between usefulness and attitude to adopt m-advertising technology is statistically significant (i.e., $\mathrm{p}<0.05$ ). Moreover, this value has provided with a positive coefficient value; which suggests that if m-advertising as a technology is perceived as useful, the attitude towards adopting the technology will be highly positive. For that reason, $\mathrm{H} 2$ is accepted.

Third hypothesis deals with the direct effect of credibility of m-advertising on adoption related behavioral outcomes. According to the findings stated in table 5 , the influence of credibility was statistically significant on attitude to adopt the said technology (i.e., $\mathrm{p}<0.05)$. Moreover, the positive coefficient value implies that if m-advertising as a technology is perceived as credible, the likelihood of adopting this technology will be very high. Consequently, H3 is accepted.

In line with the above discussion, the fourth hypothesis was about the direct effect of personalization on emotional value and consumer attitude towards adoption of madvertising technology. It can be revealed through table 5 that there is a significant influence of personalization on the emotional value because the sig value is less than 0.01 and 
insignificant with attitude of consumers where the value of $t$ is not beyond the estimated range of \pm 1.96 for the construct mentioned already. In addition, a positive coefficient value has been observed in case of significant relation; which explains that if the offering is according to consumer's need, one will feel emotional charged. Hence, H4 is accepted.

Next hypothesis deals with the mediated effects of PEOU, PU, personalization and credibility of $\mathrm{m}$-advertising on attitude to adopt mobile advertising technology. Table 5 portray the direct and mediated effect of mobile advertising components (i.e., credibility ease of use, usefulness and personalization) on consumer attitude towards m-advertising adoption through emotional value. The results revealed that two components of m-advertising (i.e., credibility and usefulness) have a significant indirect impact on mobile advertising adoption attitude through emotional value (e.g., the $\mathrm{p}$ value is lesser than 0.05 ). On the contrary, two components (such as ease of use and personalization) have insignificant indirect impact on mobile advertising adoption attitude through emotional value - as their specified $\mathrm{p}$ value is greater than the threshold (which is 0.05). Therefore, at the confidence level of $95 \%$, it can be concluded that emotional value is one of the reasons of relationship between mobile marketing components (such as credibility and usefulness) and the attitude of consumers towards adopting m-advertisements. In addition, the previous results concluded that the paths from credibility and usefulness to attitude is significant (i.e., p $<0.05$ ); in this manner it depicts partial mediation as advocated by (Hayes, 2017). In contrast, the mediated path from PEOU and personalization has been insignificant $(\mathrm{p}>0.05)$; therefore, there is no mediation (Hayes, 2017) at the confidence level of 95\%. This implies that the relationship between m-advertising technology and attitude to adoption is partially mediated by emotional value only in case of usefulness and credibility of m-advertising. As a result, H5 is partially accepted.

Considering the discussion above, it is deduced that with 95\% confidence level that PEOU [H1], usefulness [H2], credibility [H3] and personalization [H4] of mobile advertising technology have a direct impact on consumer adoption behavior. Moreover, emotional value [H5] partially mediates the relation only from usefulness and credibility to behavioral adoption. Contrary to this, personalization and PEOU do not tend to influence behavioral response through emotional value indirectly.

\section{Discussions}

\section{Ease of Use and Adoption Behavior}

According to the results, perceived ease of use (PEOU) is significantly affecting m-advertising technology adoption. This infers that if mobile marketing technology is perceptually easy to use for the consumer, it is more likely to create positive attitude towards its acceptance. Accordingly, it will create adoption intention about the technology. These findings are consistent with Bart, Stephen, and Sarvary (2014); T. T. Gao, Rohm, Sultan, and Pagani (2013) who say that mobile advertising characteristics significantly affect consumer adoption. Further, researches also agree with the fact that attitude is the main component in forming consumers adoption intention due to mobile ads (Bauer et al., 2005; Okazaki \& Mendez, 2013). However, PEOU is found insignificant to indirectly influence attitude 
towards advertising via cell phone.

\section{Usefulness and Adoption Behavior}

In terms of usefulness of mobile advertising technology, it is found to directly and indirectly affecting consumer attitude towards accepting the said technology. This infers that if mobile advertising technology is perceived as useful, it will directly transform into a positive attitude and indirectly through emotional value. Consequently it will culminate in intention to accept m-advertising technology. The findings of the study are in uniformity with the existing researches (Pantano \& Priporas, 2016) in retailing context which argue that mobile advertising characteristics significantly influence behavioral outcomes. Similarly, these findings are in favor of $\mathrm{Xu}$ (2006) who postulated that positive attitude leads to positive intentions towards performing that particular behavior which are consistent to our findings.

\section{Credibility and Adoption Behavior}

Additionally, credibility of mobile advertising is also found to be significantly effecting attitude towards adoption. This infers that if mobile advertising technology is perceived as credible, it will transform into a positive attitude. Subsequently, it will accomplish into intention to adopt that technology. These findings are steady with Oghuma, Chang, Libaque-Saenz, Park, and Rho (2015); Pantano and Priporas (2016) who argue that mobile advertising characteristics significantly influence behavioral outcomes. Similarly, these findings are in favor of Han Rebekah Wong (2012) who revealed that positive attitude of consumers towards mobile marketing would lead to positive intentions towards accepting and reading that mobile adverts.

However, it is found insignificant to indirectly influencing end-users attitude towards adoption. One of the reason of its insignificant relationship may be consumer distrust. In a developing country like Pakistan, it is common to receive messages which are usually not credible. For instance, text to win messages for Benazir Income support fund; which are prone to fraud. Now, because of their bad past experiences with deceptive mobile ads like this, they may avoid to directly processing or passing along the information right after receiving the messages.

\section{Personalization and Adoption Behavior}

In accordance with the discussion carried out above, result depicts that consumers behavior towards adoption are affected significantly by personalization. It implies that if the advertiser or the company mainly advertise their products which are relevant and are also in accordance with the requirement of the consumers, then it has the ability to transform it into positive buying behavior of the consumers. In sequential manner, if marketing of the products through mobile phone is according to beneficiary's needs, it might frame a positive attitude of the consumers and purchase intention about the product being advertised. These results are also supporting the findings of past investigations (Feng et 
al., 2016; Yuan \& Tsao, 2003) which placed that personalization plays a pivotal role in shaping consumer's positive behavior towards advertisement via mobile. These outcomes additionally connected with researches which uncovers that customers are more responsive to mobile promotions that takes care of their inclination and taste (Carroll \& Barnes, 2005; Muk, 2007).

\section{Theoretical Contribution}

Initially, this research contributes to the literature of mobile marketing by testing the proposed framework of m-advertising determinants which directly and indirectly influence adoption behavior through emotional value as focal mediator. It is worthy to mention that past researches in this context were fragmented and exploratory in nature (Kannan, 2017; Varnali \& Toker, 2010). Prominent researches (Lamberton \& Stephen, 2016) suggested to require empirical testing for understanding the overall effectiveness and their application in the domain of mobile marketing.

Second, this research has put in effort to contribute in the existing literature through conceptualizing medium related factors to ensemble into mobile marketing context. Drawing upon the TAM, m-advertising related components were sensibly chosen and altered to fit into the setting of current study. Prominently, credibility was incorporated in medium characteristics because of its unique coherence within the context of mobile marketing. In addition to this, the elements of m-advertising characteristics (i.e., ease of use, usefulness, personalization and credibility) were observed as pivotal factors of adoption within in the context of mobile market. In this way, in connection to the TAM, it is recommended to assimilate ease of use, usefulness, personalization and credibility as important indicators of adoption behavior within the context of mobile marketing.

Thirdly, this research progresses in the existing literature by investigating the indirect impact of emotional value to influence the association between m-advertising characteristics (i.e., ease of use, usefulness, personalization and credibility) and adoption behavior in mobile marketing context. The outcomes of the study uncover that the emotional values do mediate this relationship to influence adoption behavior. In this way, this research is helpful in contributing to the technological context of consumer behavior literature by suggesting emotional value as an important reason of relationship between m-advertising characteristics and adoption behavior.

\section{Practical Contribution}

First, this study found medium characteristics of mobile advertising to effect on consumer adoption behavior. These dimensions play a critical role on consumer adoption behavior in the context of mobile marketing. Therefore, marketers are suggested to use mobile media to reflect easy to process, usable and credible information and avoid complex and untrustworthy offerings to maintain consumer trust on mobile marketing activities.

Secondly, as the findings indicated that one of the reason of association between mobile marketing determinants and consumer adoption behavior is emotional value. Therefore, 
practitioners are suggested to embed emotional elements (such as entertainment, humor, feelings etc.) in their mobile marketing communication as it is the key element to influence consumer adoption. By doing so, consumer may have an emotional attachment with the marketed offerings that may bring out positive outcomes.

Lastly, the marketing practices within Asian market are mainly dependent upon western impressions; in any case, there is a considerable difference among consumers of underdeveloped and developed countries and their economies. The outcomes of this research expand the knowledge about behavior of consumers by depicting key factors which mainly influence the behavior of the consumers with regards to marketing via cell phones among developing countries, especially in South Asian nations. In the meantime, there had been a generous development in the advertising domain of the wireless technologies within the territory which demonstrates rising pattern for promoting by means of cell phones. Subsequently, these discoveries can help business experts and advertisers in South Asia by growing their insight into behavioral researches with regards to mobile marketing, and featuring the hidden association between cognitive abilities from user's point of view.

\section{Conclusion}

Conclusively, the results of the study has made apparent that there has been a positive and significant, yet partially mediated, association between m-advertising technological factors (i.e., usefulness or credibility) and behavioral response to adopt mobile advertising technology. Moreover, PEOU and personalization have only been found to directly influence attitude to adopt m-advertising technology. This, in order words, indicates the more advertising via mobile phone is considered as easy, useful, customized and credible, the higher it is likely the end-users direct their usage behavior because of the responses of communication they get from mobile marketing activities. Moreover, U\&G and extended TAM (Leung \& Wei, 2000; Venkatesh, Morris, Davis, \& Davis, 2003), also supported the mobile advertising medium acceptance on the basis of the positive relationships of credibility, PEoU and PU with behavioral outcomes. In particular, the findings based on TAM in the smartphone advertising context showed that the impact of perceived usefulness, perceived ease of use, personalization and credibility towards behavioral outcomes are positive and significant.

To summarize the discussion of the relationship between m-advertising technology related factors and path to adopt m-advertising technology, it has been found that $\mathrm{m}$ advertising characteristics directly and indirectly influence adoption behavior through emotional value as focal mediator. From empirical perspective, these findings are consistent with past researches (Bart et al., 2014; T. T. Gao et al., 2013; Pantano \& Priporas, 2016) which argue that mobile advertising characteristics significantly influence behavioral outcomes. 


\section{Limitations and Future Research Recommendations}

The present study was aimed to facilitate the readers with theoretical insights in the domain of m-advertising; however, it is not without limitations. Firstly, the prominence of present study was exclusively put on the marketing activities conducted via cell phones only. Hence, the findings of current study may be useful with caution to conduct marketing activities on other platforms - for instance, broadcast media or print media etc.

Secondly, this study was executed in Pakistan; therefore, the replication of the current research model within the context of other emerging economies, where mobile marketing has gained prevalence, require further investigations. Undoubtedly, other developing economies have different norms and cultures that may bring unprecedented behaviors of the consumers. Accordingly, depending on the extent of research, social and cultural elements may be incorporated in further studies to moderate the intensity of relationship between m-advertising components and behavioral outcomes. In addition to replicate and further test the proposed model in other developing economies, it is also suggested to consider other crucial variables of mobile technology (such as mobility, privacy, self-efficacy, interactivity and social influence) and extend current research model to better predict m-advertising adoption behavior. Lastly, emotional value as a construct was grounded from theory of consumption values (Sheth et al., 1991; Huang, Chou, \& Lin, 2010). In the original model, (Sheth et al., 1991) divided consumer values into five dimensions - namely functional value, social value, emotional value, epistemic value and conditional value. However, in current research, only one factor (i.e., emotional value) was employed and considered most appropriate. Additional types were intentionally not utilized to maintain parsimony in the current research. It is therefore, suggested for future studies to consider other dimensions of perceived values (for instance, epistemic and financial values) in different context. 


\section{References}

Ajzen, I. (1991). The theory of planned behavior. Organizational Behavior and Human Decision Processes, 50(2), 179-211.

Allen, M., Kilpatrick, D., Armstrong, M., Briggs, R., Course, G., \& Pérez, N. (2002). Multistage cluster sampling design and optimal sample sizes for estimation of fish discards from commercial trawlers. Fisheries Research, 55(1-3), 11-24.

Atrakul, B. W., \& Hu, C. P. (2017). Effects of personal values and perceived values on e-book adoption. In 2017 IEEE/ACIS 16th International Conference on Computer and Information Science (ICIS).

Aydin, G., \& Karamehmet, B. (2017). A comparative study on attitudes towards sms advertising and mobile application advertising. International Journal of Mobile Communications, 15(5), 514-536.

Bagozzi, R. P., Gopinath, M., \& Nyer, P. U. (1999). The role of emotions in marketing. Journal of the Academy of Marketing Science, 27(2), 184-206.

Balan, C., \& Zegreanu, M.-P. (2012). Insights into the development of the market of mobile marketing services in Romania. Amfiteatru Economic, 14, 786-801.

Bart, Y., Stephen, A. T., \& Sarvary, M. (2014). Which products are best suited to mobile advertising? A field study of mobile display advertising effects on consumer attitudes and intentions. Journal of Marketing Research, 51(3), 270-285.

Bauer, H. H., Reichardt, T., Barnes, S. J., \& Neumann, M. M. (2005). Driving consumer acceptance of mobile marketing: A theoretical framework and empirical study. Journal of Electronic Commerce Research, 6(3), 181.

Bruner II, G. C., \& Kumar, A. (2005). Explaining consumer acceptance of handheld internet devices. Journal of Business Research, 58(5), 553-558.

Carroll, A., \& Barnes, S. (2005). Consumers perceptions and attitudes towards SMS mobile marketing in New Zealand. International Conference on Mobile Business.

Carter, E. (2008). Mobile marketing and generation Y African-American mobile consumers: The issues and opportunities. International Journal of Mobile Marketing, 3(1), 62 66.

Chen, P.-T., \& Hsieh, H.-P. (2012). Personalized mobile advertising: Its key attributes, trends, and social impact. Technological Forecasting and Social Change, 79(3), 543557.

Creswell, J. W., \& Creswell, J. D. (2017). Research design: Qualitative, quantitative, and mixed methods approaches. Sage publications.

Cyr, D., Head, M., \& Ivanov, A. (2006). Design aesthetics leading to m-loyalty in mobile commerce. Information \& Management, 43(8), 950-963.

Daugherty, T., Logan, K., Chu, S.-C., \& Huang, S.-C. (2008). Understanding consumer perceptions of advertising: A theoretical framework of attitude and confidence. In American Academy of Advertising Conference Proceedings.

Davis, F. D., Bagozzi, R. P., \& Warshaw, P. R. (1989). User acceptance of computer technology: A comparison of two theoretical models. Management Science, 35(8), 982-1003. 
Delone, W. H., \& McLean, E. R. (2003). The DeLone and McLean model of information systems success: A ten-year update. Journal of Management Information Systems, 19(4), 9-30.

Feng, X., Fu, S., \& Qin, J. (2016). Determinants of consumers' attitudes toward mobile advertising: The mediating roles of intrinsic and extrinsic motivations. Computers in Human Behavior, 63, 334-341.

Fishbein, M., \& Ajzen, I. (1977). Belief, attitude, intention, and behavior: An introduction to theory and research. Addison-Wesley Pub. Co.

Fornell, C., \& Larcker, D. F. (1981). Structural equation models with unobservable variables and measurement error: Algebra and statistics. Journal of Marketing Research, $18(3), 382-388$.

Friedrich, R., Gröne, F., Hölbling, K., \& Peterson, M. (2009). The march of mobile marketing: New chances for consumer companies, new opportunities for mobile operators. Journal of Advertising Research, 49(1), 54-61.

Gao, S., \& Zang, Z. (2016). An empirical examination of users' adoption of mobile advertising in China. Information Development, 32(2), 203-215.

Gao, T. T., Rohm, A. J., Sultan, F., \& Pagani, M. (2013). Consumers un-tethered: A three-market empirical study of consumers' mobile marketing acceptance. Journal of Business Research, 66(12), 2536-2544.

Gendron, M., \& Barrett, L. F. (2018). Emotion perception as conceptual synchrony. Emotion Review, 10(2), 101-110.

Grant, I., \& O'Donohoe, S. (2007). Why young consumers are not open to mobile marketing communication. International Journal of Advertising, 26(2), 223-246.

Gratch, J., \& Marsella, S. (2004). A domain-independent framework for modeling emotion. Cognitive Systems Research, 5(4), 269-306.

Hair, J. F., Hult, G. T., Ringle, C. M., \& Sarstedt, M. (2016). A primer on partial least squares structural equation modeling (PLS-SEM). Los Angeles: SAGE.

Han Rebekah Wong, S. (2012). Which platform do our users prefer: Website or mobile app? Reference Services Review, 40(1), 103-115.

Hayes, A. F. (2017). Introduction to mediation, moderation, and conditional process analysis: A regression-based approach. New York: Guilford Publications.

Henseler, J., Ringle, C. M., \& Sinkovics, R. R. (2009). The use of partial least squares path modeling in international marketing. United Kingdom: Emerald Group Publishing Limited.

Howell, D. C. (2012). Statistical methods for psychology. Cengage Learning.

Hsu, C.-L., \& Lin, J. C.-C. (2015). What drives purchase intention for paid mobile apps? An expectation confirmation model with perceived value. Electronic Commerce Research and Applications, 14(1), 46-57.

Huang, C.-Y., Chou, C.-J., \& Lin, P.-C. (2010). Involvement theory in constructing bloggers' intention to purchase travel products. Tourism Management, 31(4), 513526 .

Kalaiarasi, H., \& Srividya, V. (2012). A study on wireless banking services-the case of mobile banking with integrated technology acceptance model. Journal of Contemporary Research in Management, 7(3), 31-40. 
Kannan, P. K. (2017). Digital marketing: A framework, review and research agenda. International Journal of Research in Marketing, 34(1), 22-45.

Kim, H.-W., Chan, H. C., \& Gupta, S. (2007). Value-based adoption of mobile internet: An empirical investigation. Decision Support Systems, 43(1), 111-126.

Kim, M.-K., Joo, C., \& Park, J.-H. (2017). Investigating the determinants of low adoption of tablet PCs in Korean firms: Effects of value perception and alternative attractiveness. Telematics and Informatics, 34 (8), 1557-1571.

Kim, Y. J., \& Han, J. (2014). Why smartphone advertising attracts customers: A model of web advertising, flow, and personalization. Computers in Human Behavior, 33, 256-269.

Ladhari, R., Souiden, N., \& Dufour, B. (2017). The role of emotions in utilitarian service settings: The effects of emotional satisfaction on product perception and behavioral intentions. Journal of Retailing and Consumer Services, 34, 10-18.

Lamberton, C., \& Stephen, A. T. (2016). A thematic exploration of digital, social media, and mobile marketing: Research evolution from 2000 to 2015 and an agenda for future inquiry. Journal of Marketing, 80(6), 146-172.

Lee, T., \& Jun, J. (2007). Contextual perceived value? Investigating the role of contextual marketing for customer relationship management in a mobile commerce context. Business Process Management Journal, 13(6), 798-814.

Leppäniemi, M., \& Karjaluoto, H. (2008). Exploring the effects of gender, age, income and employment status on consumer response to mobile advertising campaigns. Journal of Systems and Information Technology, 10(3), 251-265.

Leung, L., \& Wei, R. (2000). More than just talk on the move: Uses and gratifications of the cellular phone. Journalism \& Mass Communication Quarterly, 7r(2), 308-320.

Lim, J. S., Ri, S. Y., Egan, B. D., \& Biocca, F. A. (2015). The cross-platform synergies of digital video advertising: Implications for cross-media campaigns in television, internet and mobile TV. Computers in Human Behavior, 48, 463-472.

Liu, Z., Gao, X., \& Long, X. (2010). Adaptive random testing of mobile application. In 2010 2nd International Conference on Computer Engineering and Technology (pp. 297-301).

Lutz, R. J., MacKenzie, S. B., \& Belch, G. E. (1983). Attitude toward the ad as a mediator of advertising effectiveness: Determinants and consequences. ACR North American Advances, 10(1), 532-539.

MacKenzie, S. B., \& Lutz, R. J. (1989). An empirical examination of the structural antecedents of attitude toward the ad in an advertising pretesting context. Journal of Marketing, 53(2), 48-65.

Maduku, D. K., Mpinganjira, M., \& Duh, H. (2016). Understanding mobile marketing adoption intention by South African SMEs: A multi-perspective framework. International Journal of Information Management, 36(5), 711-723.

Mathieson, K. (1991). Predicting user intentions: comparing the technology acceptance model with the theory of planned behavior. Information Systems Research, 2(3), 173-191.

Moon, J.-W., \& Kim, Y.-G. (2001). Extending the TAM for a world-wide-web context. Information \& Management, 38(4), 217-230. 
Muk, A. (2007). Consumers' intentions to opt in to SMS advertising: A cross-national study of young Americans and Koreans. International Journal of Advertising, 26(2), $177-198$.

Muk, A., \& Chung, C. (2015). Applying the technology acceptance model in a two-country study of SMS advertising. Journal of Business Research, 68(1), 1-6.

Nah, F. F.-H., Siau, K., \& Sheng, H. (2005). The value of mobile applications: A utility company study. Communications of the ACM, 48(2), 85-90.

Nel, J., \& Boshoff, C. (2017). Development of application-based mobile-service trust and online trust transfer: An elaboration likelihood model perspective. Behaviour $\&$ Information Technology, 36(8), 809-826.

Nunnally, J. C., \& Bernstein, I. (1978). Psychometric testing. New York: McGraw-Hill.

Nysveen, H., Pedersen, P. E., Thorbjørnsen, H., \& Berthon, P. (2005). Mobilizing the brand: The effects of mobile services on brand relationships and main channel use. Journal of Service Research, 7(3), 257-276.

Oghuma, A. P., Chang, Y., Libaque-Saenz, C. F., Park, M.-C., \& Rho, J. J. (2015). Benefit-confirmation model for post-adoption behavior of mobile instant messaging applications: A comparative analysis of KakaoTalk and Joyn in Korea. Telecommunications Policy, 39(8), 658-677.

Okazaki, S., \& Mendez, F. (2013). Perceived ubiquity in mobile services. Journal of Interactive Marketing, 27(2), 98-111.

Oliver, R. L. (1996). Varieties of value in the consumption satisfaction response. ACR North American Advances, 23, 143-147.

Ovčjak, B., Heričko, M., \& Polančič, G. (2016). How do emotions impact mobile services acceptance? A systematic literature review. Mobile Information Systems. doi: 10 $.1155 / 2016 / 8253036$

Pagani, M., \& Malacarne, G. (2017). Experiential engagement and active vs. passive behavior in mobile location-based social networks: The moderating role of privacy. Journal of Interactive Marketing, 37, 133-148.

Pantano, E., \& Priporas, C.-V. (2016). The effect of mobile retailing on consumers' purchasing experiences: A dynamic perspective. Computers in Human Behavior, $61,548-555$.

Peterson, R. A., \& Kim, Y. (2013). On the relationship between coefficient alpha and composite reliability. Journal of Applied Psychology, 98(1), 194-198.

Pura, M., \& Gummerus, J. (2007). Discovering value perceptions of mobile services with critical incident technique (CIT). Marketing Theory and Applications, 35.

Schierz, P. G., Schilke, O., \& Wirtz, B. W. (2010). Understanding consumer acceptance of mobile payment services: An empirical analysis. Electronic Commerce Research and Applications, 9(3), 209-216.

Sheng, M. L., \& Teo, T. S. (2012). Product attributes and brand equity in the mobile domain: The mediating role of customer experience. International Journal of Information Management, 32(2), 139-146.

Sheth, J. N., Newman, B. I., \& Gross, B. L. (1991). Why we buy what we buy: A theory of consumption values. Journal of Business Research, 22(2), 159-170. 
Soutar, G. N., \& Sweeney, J. C. (2003). Are there cognitive dissonance segments? Australian Journal of Management, 28(3), 227-249.

Sultan, F., \& Rohm, A. (2005). The coming era of "brand in the hand" marketing: The growing popularity of cell phones and other hand-held mobile devices has opened up new marketing possibilities. MIT Sloan Management Review, 47(1), 83-91.

Szajna, B. (1996). Empirical evaluation of the revised technology acceptance model. Management Science, 42(1), 85-92.

Tanakinjal, G. H., Deans, K. R., \& Gray, B. J. (2010). Third screen communication and the adoption of mobile marketing: A Malaysia perspective. International Journal of Marketing Studies, 2(1), 36-47.

Turow, J., King, J., Hoofnagle, C. J., Bleakley, A., \& Hennessy, M. (2009). Americans reject tailored advertising and three activities that enable it. Available at SSRN 1478214 .

Van Ittersum, K., \& Feinberg, F. M. (2010). Cumulative timed intent: A new predictive tool for technology adoption. Journal of Marketing Research, 47(5), 808-822.

Varnali, K., \& Toker, A. (2010). Mobile marketing research: The-state-of-the-art. International Journal of Information Management, 30(2), 144-151.

Venkatesh, V. (1999). Creation of favorable user perceptions: Exploring the role of intrinsic motivation. MIS Quarterly, 239-260.

Venkatesh, V., \& Davis, F. D. (1996). A model of the antecedents of perceived ease of use: Development and test. Decision Sciences, $27(3), 451-481$.

Venkatesh, V., \& Davis, F. D. (2000). A theoretical extension of the technology acceptance model: Four longitudinal field studies. Management Science, 46(2), 186-204.

Venkatesh, V., \& Morris, M. G. (2000). Why don't men ever stop to ask for directions? gender, social influence, and their role in technology acceptance and usage behavior. MIS Quarterly, 115-139.

Venkatesh, V., Morris, M. G., Davis, G. B., \& Davis, F. D. (2003). User acceptance of information technology: Toward a unified view. MIS Quarterly, 425-478.

Wakefield, R. L., \& Whitten, D. (2006). Mobile computing: A user study on hedonic/utilitarian mobile device usage. European Journal of Information Systems, 15(3), 292-300.

Wang, Y., Po Lo, H., Chi, R., \& Yang, Y. (2004). An integrated framework for customer value and customer-relationship-management performance: A customer-based perspective from China. Managing Service Quality: An International Journal, $14(2 / 3)$, 169-182.

Wong, K. K.-K. (2013). Partial least squares structural equation modeling (PLS-SEM) techniques using SmartPLS. Marketing Bulletin, 24(1), 1-32.

$\mathrm{Xu}$, D. J. (2006). The influence of personalization in affecting consumer attitudes toward mobile advertising in China. Journal of Computer Information Systems, 47(2), 9-19.

Yeong, K. K., Kheng, M. Y., Leong, S.-Y., \& Tan, H. Q. (2017). Consumers' acceptance towards location-based social networking services. (Unpublished doctoral dissertation). UTAR.

Yoo, Y., \& Alavi, M. (2001). Media and group cohesion: Relative influences on social presence, task participation, and group consensus. MIS Quarterly, 371-390. 
Yuan, S.-T., \& Tsao, Y. W. (2003). A recommendation mechanism for contextualized mobile advertising. Expert Systems with Applications, 24(4), 399-414.

Zarmpou, T., Saprikis, V., Markos, A., \& Vlachopoulou, M. (2012). Modeling users' acceptance of mobile services. Electronic Commerce Research, 12(2), 225-248. 